\title{
Komunikasi Antarbudaya Etnis Rohingya dalam Upaya Eksistensi Diri Di Pengungsian Kota Medan
}

\author{
Nora Maya Siregar, Amru Lubis*) \\ Program Studi Ilmu Komunikasi Universitas Muhammadiyah Sumatera Utara dan \\ Jurnalis Harian Analisa Medan, Indonesia \\ Koresponden:noramayasrg@gmail.com
}

\begin{abstract}
ABSTRAK
Tujuan kajian dalam penelitian ini untuk mengetahui bagaimana komunikasi antarbudaya dan bentuk-bentuk adaptasi etnis Rohingya dalam upaya eksistensi diri di Hotel Pelangi Kota Medan. Terdapat dua teori yang mendasari penelitian ini, yaitu teori akomodasi komunikasi dan teori adaptasi. Teori akomodasi komunikasi digunakan untuk menjelaskan bagaimana proses komunikasi antarbudaya etnis Rohingya dalam interaksi. Teori adaptasi digunakan untuk menjelaskan bagaimana bentuk-bentuk adaptasi etnis Rohingya dalam upaya eksistensi diri. Metode penelitian yang digunakan dalam penelitian ini adalah metode deskriptif kualitatif. Pengumpulan data dilakukan dengan melakukan observasi dan wawancara mendalam terhadap informan penelitian. Hasil penelitian ini memperlihatkan bahwa dalam hubungan sosial yang berlangsung pada etnis Rohingya di Hotel Pelangi Kota Medan menimbulkan terjadinya proses sosial yang asosiatif yakni akomodasi. Akomodasi merupakan proses penyesuaian sosial yang terjadi dalam sebuah interaksi sehingga proses penyesuaian sosial tersebut, etnis Rohingya tidak terlepas dari komunikasi dan budaya.
\end{abstract}

Kata kunci : Komunikasi Antarbudaya, Adaptasi, Rohingya.

\begin{abstract}
The purpose of this study is to find out how intercultural communication and forms of Rohingya ethnic adaptation in an effort to exist in the Pelangi Hotel, Medan City. There are two theories that underlie this research, namely the theory of accommodation accommodation and the theory of adaptation. Communication accommodation theory is used to explain how the Rohingya ethnic intercultural communication processes interact. Adaptation theory is used to explain how Rohingya forms of adaptation in self-existence. The research method used in this research is descriptive qualitative method. Data collection is done by conducting observations and in-depth interviews with research informants. The results of this study indicate that the social relationships that take place on the Rohingya ethnic group at the Pelangi Hotel in Medan cause an associative social process that is accommodation. Accommodation is a process of social adjustment that occurs in an interaction so that the process of social adjustment, Rohingya ethnic can not be separated from communication and culture.
\end{abstract}

Keywords: Intercultural Communication, Adaptation, Rohingya.

\section{Pendahuluan}

Rohingya merupakan salah satu etnis yang mendapatkan perlakuan diskriminasi yang dimulai sejak Myanmar merdeka dan dipimpin oleh rezim Junta militer. Pemerintahan Junta militer Myanmar yang telah berkuasa sejak tahun 1962 memang dikenal sebagai rezim pemerintahan yang paling represif di dunia (Freedom House: 2003) (Adelia, 2013: 2). 
Pemerintah Myanmar tidak mengakui etnis Rohingya sebagai bagian dari 135 kelompok etnis resmi di Myanmar.Tidak seperti etnis lain yang setidaknya diakui warganegaranya oleh Myanmar, masyarakat Rohingya dianggap sebagai penduduk sementara. Sebagai "orang asing", masyarakat Rohingya tidak diperbolehkan bekerja sebagai pengajar, perawat, abdi masyarakat atau dalam layanan masyarakat Mereka, dianggap sebagai orang-orang yang tak bernegara dan tidak diakui oleh pemerintah Myanmar. Etnis yang terletak di Myanmar Utara ini terpinggirkan oleh pemerintahan junta militer dan di wilayah Rohingya, para pengajarnya biasanya berasal dari golongan etnis Budha Rakhine, yang seringkali menghalangi kesempatan untuk mendapatkan pendidikan bagi masyarakat Rohingya. Pemerkosaan dan kerja paksa adalah hal yang cukup lazim bagi etnis Rohingya di Myanmar.

Tentara Myanmar kerapkali meminta uang dari mereka dan ketika mereka tidak dapat membayar, mereka akan ditahan dan disiksa. Masyarakat Rohingya juga mengalami penyiksaan secara religi. Hampir seluruh masyarakat Rohingya adalah beragama Islam. Dalam tiga tahun terakhir, setidaknya 12 Masjid di Arakan Utara dihancurkan, dengan jumlah terbesar di tahun 2006. Sejak 1962, tidak ada Masjid baru yang dibangun. Bahkan para pemimpin agama telah dipenjara karena merenovasi Masjid (Anna, 2013: 12). Oleh sebab itu, mereka terpaksa meninggalkan negaranya dan menyatakan dirinya sebagai pencari suaka. Mereka terombangambing di laut lepas berlayar menggunakan kapal hingga akhirnya negara Indonesia dan bekerjasama dengan badan pengungsi PBB memberikan tempat penampungan bagi imigran ilegal tersebut di beberapa Rudenim di Indoesia seperti Rudenim Tanjung Pinang, Aceh dan Medan. Dan di beberapa lokasi camp pengungsian seperti di Hotel Pelangi Kota Medan.

Kota Medan sebagai salah satu wilayah terbesar ketiga di Indonesia setelah Jakarta dan Surabaya serta kota yang berbatasan langsung dengan selat Malaka, menjadikan Kota Medan sebagai kota yang mudah didatangi oleh para pendatang. Oleh sebab itu, kota Medan sebagai salah satu kota bagian dari Negara Indonesia yang menjunjung tinggi Hak Asasi Manusia (HAM), atas dasar kemanusiaan merasa terpanggil dan bersedia menyediakan penampungan sementara bagi para pengungsi etnis Rohingya yang terjebak pada konflik yang tidak berkesudahan. Etnis Rohingya yang berada di camp pengungsian Hotel Pelangi ini berada di bawah pengawasan Rumah Detensi Imigrasi (Rudenim) Medan. Para pengungsi juga mendapatkan bantuan sandang dan pangan dari PBB yang disalurkan melalui International Organization for Migration (IOM) dan United Nations Hight Commisioner For Refugees (UNHCR) (sumber: medan.tribunnews.com).

Demikian halnya dengan kedatangan etnis Rohingya di kota Medan. Mereka merupakan etnis yang melakukan proses perpindahan dengan latar belakang kebudayaan yang berbeda. Namun perpindahan etnis Rohingya ini bukanlah perpindahan yang dilakukan secara sukarela. Melainkan didasarkan oleh situasi dan kondisi yang menyebabkan mereka terpaksa melakukan perpindahan.

Etnis Rohingya membutuhkan penyesuaian diri untuk dapat menerima tekanan-tekanan atau masalah-masalah sebagai konsekuensi dari pilihan yang diambil terutama untuk dapat menerima dirinya adalah sebagai pengungsi/pencari suaka yang terikat dengan peraturan negara penerimanya di Indonesia yaitu sesuai dengan Peraturan Presiden Republik Indonesia (PERPRES) Nomor 125 tahun 2016 tentang Penanganan Pengungsi Dari Luar Negeri. Peraturan tersebut harus dipenuhi meskipun dalam keterpaksaan. Beberapa situasi menghendaki supaya seseorang secara aktif membentuk nasibnya, sedangkan para etnis Rohingya menjalani kehidupan di camp pengungsian tersebut dalam stuasi-situasi lain yang menghendaki supaya dirinya dapat menerima situasi tersebut apa adanya yaitu kondisi kehidupan sebagai pengungsi yang tidak mempunyai status kewarganegaraan. Berdasarkan observasi awal penulis, tidak banyak aktivitas yang bisa mereka lakukan di kamp pengungsian Hotel Pelangi Medan. 
Vol 2 No. 2, 2019, 70-86

DOI: https://doi.org/10.30596/persepsi.v2i2.3951

Mereka tidak bisa hidup seperti orang-orang pada umumnya. Mereka tidak dapat bekerja, menikah, dan anak-anak terbatas untuk memperoleh pendidikan karena tidak mempunyai negara.

\section{Kerangka Teori}

Adhiputra (Ridwan, 2016: 94-95) interaksi adalah hal saling melakukan aksi, berhubungan, memengaruhi antarhubungan. Interaksi adalah jenis tindakan aksi yang terjadi ketika dua atau lebih objek memengaruhi atau memiliki efek satu sama lain. Interaksi antarbudaya yang efektif sangat bergantung pada komunikasi antarbudaya. Konsep ini sekaligus menerangkan bahwa tujuan komunikasi antarbudaya akan tercapai apabila bentuk hubungan antarbudaya menggambarkan upaya yang sadar dari peserta komunikasi untuk memperbarui relasi antara komunikator dengan komunikan, menciptakan dan memperbarui manajemen komunikasi yang aktif, lahirnya semangat kesetiakawanan, persahabatan, hingga berhasilnya pembagian teknologi, mengurangi konflik yang seluruhnya merupakan bentuk dari komunikasi antarbudaya.

Granovetter (Ridwan, 2016: 133-134) proses yang timbul sebagai akibat adanya interaksi sosial, yaitu sebagai berikut:

1) Proses Asosiatif

Proses asosiatif terbagi dalam tiga bentuk khusus, yaitu sebagai berikut:

a) Kerjasama, yaitu usaha bersama antara orang perseorangan atau kelompok manusia untuk mencapai satu atau beberapa tujuan bersama.

b) Akomodasi, yaitu proses penyesuaian sosial dalam interaksi antara pribadi dan kelompok manusia untuk meredakan pertentangan.

c) Asimilasi, yaitu proses sosial yang timbul apabila ada kelompok masyarakat dengan latar belakang kebudayaan yang berbeda saling bergaul secara intensif dalam jangka waktu lama, sehingga lambat laun kebudayaan aslinya berubah sifat dan membentuk kebudayaan baru sebagai kebudayaan campuran.

2) Proses Disosiatif

a) Persaingan, yaitu perjuangan yang dilakukan perorangan atau kelompok sosial tertentu agar memperoleh kemenangan atau hasil secara kompetitif, tanpa menimbulkan ancaman atau benturan fisik di pihak lawannya.

b) Kontraversi, yaitu proses sosial yang berada diantara persaingan dan pertentangan atau konflik. Wujud kontraversi, antara lain sikap tidak senang, baik secara tersembunyi maupun secara terang- terangan yang ditujukan terhadap perseorangan atau kelompok atau terhadap unsur-unsur kebudayaan tertentu. Sikap tersebut dapat berubah menjadi kebencian, tetapi tidak sampai menjadi pertentangan atau konflik.

c) Pertentangan, yaitu proses sosial antarindividu atau kelompok masyarakat tertentu, akibat adanya perbedaan paham dan kepentingan yang sangat mendasar sehingga menimbulkan jurang pemisah yang mengganjal interaksi sosial di antara mereka yang bertikai.

Teori Akomodasi Komunikasi

West dan Turner (Ridwan, 2016: 53) teori akomodasi komunikasi berawal pada tahun 1973, ketika Howard Giles pertama kali memperkenalkan pemikiran mengenai model mobilitas aksen, yang didasarkan pada berbagai aksen yang dapat didengar dalam situasi wawancara. Akomodasi didefinisikan sebagai kemampuan untuk menyesuaikan, memodifikasi, atau mengatur perilaku seseorang dalam responnya terhadap orang lain. 
Orizal, Nuraeni dan Imran (2016: 6) tujuan inti dari teori akomodasi komunikasi adalah untuk menjelaskan cara-cara dimana orang-orang yang berinteraksi dapat mempengaruhi satu sama lain selama interaksi. Teori akomodasi komunikasi berfokus pada mekanisme dimana proses psikologi sosial mempengaruhi perilaku yang diamati dalam interaksi. Akomodasi merunjuk pada cara-cara dimana individu-individu dalam interaksi, memantau dan mungkin menyesuaikan perilaku mereka selama interaksi (Rohim, 2009: 212).

Teori akomodasi komunikasi menyatakan bahwa dalam sebuah interaksi, seseorang memiliki pilihan. Mereka mungkin menciptakan komunitas percakapan yang melibatkan penggunaan bahasa atau sistem nonverbal yang sama, mereka mungkin akan membedakan diri mereka dari orang lain, atau mereka akan berusaha keras untuk beradaptasi. Pilihan ini diberi label konvergensi, divergensi, dan akomodasi berlebihan.

a) Konvergensi: Jasse Delia, Nikolas Coupland, dan Justin Couplan (Ridwan, 2016: 54) mendefinisikan konvergensi sebagai strategi individu beradaptasi terhadap perilaku komunikatif satu sama lain. Seseorang akan beradaptasi terhadap kecepatan bicara, jeda, senyuman, tatapan mata, perilaku verbal dan non verbal lainnya. Ketika orang melakukan konvergensi, Ia bergantung pada persepsinya mengenai tuturan atau perilaku orang lain, konvergensi juga didasarkan pada ketertarikan. Ketika komunikator saling tertarik, Ia akan melakukan konvergensi dalam percakapan.

b) Divergensi: Reisinger (Priandono, 2016: 68) mendefinisikan komunikasi divergen yaitu pembicara mencari perbedaan antara gaya komunikasi mereka untuk meningkatkan jarak komunikatif dan meningkatkan keunikan mereka. Semakin banyak pembicara menyimpang dari pasangannya, dampak yang kurang menguntungkan tersebut kemungkinan akan dievaluasi. Lawan bicara kemudian mengacu melanjutkan gaya bicara sendiri. Teori bisa digambarkan ketika komunikasi antaretnis, kemudian menggunakan bahasa atau dialek yang membuat orang lain yang berbeda budaya dan tidak memahami bahasa atau dialek yang digunakan menjadi tidak merasa nyaman.

Menurut Giles (Yohana dan Yozani, 2017: 98) pembicara yang melakukan akomodasi divergensi cenderung menonjolkan perbedaan verbal dan non verbal di antara mereka sendiri dan orang lain. Alih-alih menunjukkan bagaimana dua pembicara mirip dalam kecepatan bicara, tindak-tanduk atau postur, divergensi adalah ketika tidak terdapat usaha untuk menunjukkan persamaan antara para pembicara. Dengan kata lain, dua orang berbicara dengan satu sama lain tanpa adanya kekhawatiran mengenai mengakomodasi satu sama lain.

c) Akomodasi berlebihan: miscommunication dengan tujuan. Jane Zuengler (Ridwan, 2016: 55) mengamati bahwa akomodasi berlebihan adalah label yang diberikan kepada pembicara yang dianggap terlalu berlebihan. Istilah ini diberikan kepada orang yang bertindak berdasarkan niat baik, tetapi dianggap merendahkan.

\section{Adaptasi Budaya}

Istilah adaptasi berasal dari kata dalam bahasa Latin adaptare, yang artinya 'untuk menyesuaikan'. Adaptasi sosial (kultural) adalah modifikasi atau penyesuaian perilaku personal yang penting untuk mempertahankan interaksi yang harmonis dengan individu lain dalam kelompok (akomodasi sosial), seperti konformitas terhadap adat (atau tabu) dari kelompok sosial tertentu (Roeckelein, 2013: 12-14).

Adaptasi juga bisa diartikan sebagai cara-cara yang dipakai oleh perantau untuk mengatasi rintangan-rintangan yang mereka hadapi dan untuk memperoleh keseimbangankeseimbangan positif dengan kondisi latar belakang perantau (Pelly, 1998: 83).

Pada awalnya, kajian tentang adaptasi budaya ini didasari oleh pekerja- pekerja imigran dan mahasiwa yang belajar lintas negara di Eropa. Kajian ini dirasa penting untuk menyambut interaksi global yang saat ini sudah menjadi kebiasaan dan semakin banyak terjadi. 
Ketika seorang jauh dari rumah, jauh dari tempat yang selama ini dianggap sebagai "rumah" jauh dari lingkungan tempat dia tumbuh besar, dan jauh dari kebiasaan-kebiasaan yang selalu dia lakukan. Orang tersebut mau tidak mau akan sadar atau tidak akan mempelajari hal-hal yang baru untuk bisa bertahan hidup (Ruben dan Stewart, 2006: 340).

Young Y. Kim (Ruben dan Stewart, 2006: 342) menguraikan dan menggambarkan langkah-langkah dalam proses pengadaptasian sebuah budaya. Secara umum ada empat fase ditambah dengan fase perencanaan. Berikut penjelasan singkat mengenai fase-fase dalam proses pengadaptasian budaya:

a. Fase perencanaan

Fase ini adalah fase dimana seseorang masih berada pada kondisi asalnya dan menyiapkan segala sesuatu, mulai dari ketahanan fisik sampai kepada mental, termasuk kemampuan komunikasi yang dimiliki untuk dipersiapkan, yang nantinya digunakan pada kehidupan barunya.

b. Fase Honeymoon

Fase ini adalah fase dimana seseorang telah berada di lingkungan baru, menyesuaikan diri dengan budaya baru dan lingkungan. Tahap ini adalah tahap dimana seseorang masih memiliki semangat dan rasa penasaran yang tinggi serta menggebu-gebu dengan suasana baru yang akan dijalani.

Individu tersebut mungkin tetap akan merasa asing, kangen rumah dan merasa sendiri namun masih terlena dengan keramahan penduduk lokal terhadap orang asing.

c. Fase Frustation

Fase ini adalah tahap dimana rasa semangat dan penasaran yang menggebu- gebu tersebut berubah menjadi rasa frustasi, jengkel dan tidak mampu berbuat apa-apa karena realita yang sebenarnya tidak sesuai dengan ekspetasi yang di miliki pada awal tahapan.

d. Fase Readjustment

Tahap ini adalah tahap penyesuaian kembali, dimana seseorang akan mulai untuk mengembangkan berbagai macam cara untuk bisa beradaptasi dengan keadaan yang ada. Seseorang mulai menyelesaikan krisis yang dialami di fase frustation. Penyelesaian ini ditandai dengan proses penyesuaian ulang dari seseorang untuk mencari cara, seperti mempelajari bahasa, dan budaya setempat.

e. Fase Resolution

Fase yang terakhir dari proses adaptasi budaya berupa jalan akhir yang diambil seseorang sebagai jalan keluar dari ketidaknyamanan yang dirasakannya.

\section{Eksistensi Diri}

Istilah eksistensi berasal dari kata existere $(\mathrm{eks}=$ keluar, sistere $=$ ada atau berada. Dengan demikian eksistensi memiliki arti sebagai "sesuatu yang sanggup keluar dari keberadaannya" atau "sesuatu yang mampu melampaui dirinya sendiri". Dalam kenyataan hidup sehari-hari tidak ada sesuatupun yang mempunyai ciri atau karakter existere, selain manusia. Hanya manusia yang bereksistensi. Hanya manusia yang sanggup keluar dari dirinya, melampaui keterbatasan biologis dan lingkungan fisiknya, berusaha untuk tidak terkungkung oleh segala keterbatasan yang dimilikinya (Zainal Abidin, 2014: 33).

Akar atau dasar dari eksistensi sendiri bermula pada pandangan bahwa manusia selalu hidup dalam bahaya yang tidak akan pernah lepas dari kecemasan, ketakutan, dan fakta akan kematian (rodgers \& Thompson, 2015) Pratiwi (2016:13). Kondisi-kondisi inilah yang mendorong manusia untuk mewujudkan eksistensi dirinya dengan merealisasikan kemungkinankemungkinan yang ada dalam rangka mencapai kehidupan yang lebih bermakna. 
Loonstra, Brouwers, \& Tomic (2007) (Pratiwi (2016 :13) mengartikan eksistensi diri sebagai kesadaran manusia terhadap tujuan hidup dan dengan sepenuhnya dapat menerima potensi serta batasan diri secara hakiki. Abidin (2002) (Pratiwi, 2016: 20-24) mengemukakan beberapa faktor yang mempengaruhi eksistensi diri, antara lain :

a. Kematian (Ketiadaan): eksistensi manusia tidak lepas dari kematian. Kematian merupakan akhir dari eksistensi manusia. Namun, kematian dapat membuat seseorang menjadi diri yang autentik apabila ia dapat menerima kematian sebagai suatu fakta yang tidak terpisahkan dari eksistensinya. Apabila manusia dapat menerima kematian yang identik dengan ketiadaan dan kesendirian yang mencekam dan menyeluruh, maka ia akan berusaha melepaskan diri diri kontrol dengan orang lain. Kuasa atau kontrol orang lain inilah yang membuat eksistensi seseorang dangkal atau tidak autentik.

b. Kecemasan: kecemasan (angst atau anxiety) dalam hal ini berhubungan dengan kebebasan. Manusia adalah makhluk satu-satunya yang hidup bebas di dunia. Namun, kebebasan tersebut justru membuat manusia menjadi cemas karena selalu dihadapkan pada berbagai kemungkinan. Manusia tidak pernah tahu apakah kemungkinan-kemungkinan tersebut akan baik atau justru menghancurkan eksistensi dirinya. Dengan kata lain, kecemasan tersebut disebabkan karena adanya kesadaran manusia akan kebebasan dimana semua resikonya menuntut pertanggungjawaban.

c. Kehendak Bebas: setiap saat manusia dihadapkan pada kondisi untuk memilih satu atau beberapa kemungkinan-kemungkinan yang ada. Manusia berhak sepenuhnya untuk memilih apa yang ia inginkan, dan karenanya manusia disebut sebagai makhluk yang bebas. Tindakan-tindakan manusia pada dasarnya mengisyaratkan adanya kehendak bebas, misalnya :

1) Penentuan diri (self determination). Dalam menentukan sebuah pilihan dalam hidup, manusia dapat menerima masukan dari orang lain tentang baik atau buruknya hal-hal yang sedang dihadapi. Walaupun demikian, pada akhirnya penentuan pilihan tersebut bukan berasal dari orang lain, melainkan keputusan dari diri sendiri.

2) Pilihan. Pilihan yang diambil akan menghasilkan tindakan yang dilakukan saat ini. 3) Konsekuensi. Tidak semua konsekuensi sesuai dengan yang diprediksikan. Terkadang, ada tindakan baik namun malah berakibat buruk. 4) Pertanggungjawaban. Setiap manusia bertanggung jawab atas semua konsekuensi dari tindakan yang dilakukannya. 5) Karakter. Setiap pilihan tindakan yang diambil seseorang, menciptakan pribadinya, misalnya apakah seseorang memilih menjadi seorang pemarah, penyabar, atau pemberani. Ketika memilih, sesesorang akan melakukan tindakan dan tindakan tersebut yang membentuk karakter dirinya.

\section{Metode}

Jenis penelitian yang digunakan adalah jenis penelitian deskriptif dengan pendekatan kualitatif. Nawawi (2003: 20) penelitian deskriptif dapat diartikan sebagai prosedur pemecahan masalah yang diselidiki dengan menggambarkan atau melukiskan keadaan subjek atau objek penelitian (seseorang, lembaga, masyarakat, dan lain-lain) pada saat ini berdasarkan fakta-fakta yang tampak atau sebagaimana adanya.

Pada pendekatan ini, peneliti membuat suatu gambaran kompleks, meneliti kata-kata, laporan terinci dari pandangan responden, dan melakukan studi pada situasi yang alami, sdangkan menurut Taylor dan Bogdan (Suyanto, 2005: 166) penelitian kualitatif dapat diartikan sebagai penelitian yang menghasilkan data deskriptif mengenai kata-kata lisan maupun tertulis, dan tingkah laku yang dapat diamati dari orang-orang yang diteliti.

Data kualitatif menurut Kriyantono (2006 : 196) adalah data yang berbentuk kata-kata, kalimatkalimat, narasi-narasi, baik yang diperoleh dari wawancara mendalam maupun dari observasi. 
Data ini berhubungan dengan kategorisasi, karakteristik berwujud pertanyaan atau berupa katakata. Tahap analisis data memegang peran penting dalam riset kualitatif, yaitu sebagai faktor utama penilaian kualitas tidaknya riset. Riset kualitatif adalah riset yang menggunakan cara berpikir induktif, yaitu cara berpikir yang berangkat dari hal-hal yang khusus (empiris) menuju hal-hal yang umum (tataran konsep). di Jl. Letjen Jamin Ginting. No. 18A. Simpang Selayang, Medan Tuntungan, Kota Medan, Sumatera Utara. Kode pos: 20135. Lokasi tersebut dipilih karena memiliki semua aspek pendukung agar penelitian dapat berjalan dengan baik. Adapun waktu penelitian ini dilaksanakan pada tanggal 3 Januari hingga tanggal 13 Maret 2018.

\section{Hasil dan Pembahasan Hasil Penelitian}

Berdasarkan fenomena yang diamati dan data yang diperoleh melalui hasil wawancara di lapangan. Etnis muslim Rohingya yang berasal dari Rakhine (Myanmar) melakukan perpindahan dalam keadaan terpaksa karena konflik yang terjadi di negara asalnya yaitu Myanmar. Etnis Rohingya ini tidak diakui sebagai salah satu kelompok etnis resmi di Myanmar. Banyak bentukbentuk perlakuan tidak manusiawi yang mereka dapatkan selama berada di Myanmar. Bentuk-bentuk perlakuan tersebut antara lain, seperti pembakaran pada rumah-rumah mereka, perampasan harta benda oleh tentara militer Myanmar, pemerkosaan terhadap perempuan, penindasan dan kerja paksa, bahkan penyiksaan dan pembunuhan adalah hal yang sudah lazim terjadi. Hal ini sesuai dengan data yang diperoleh melalui wawancara kepada informan pada pertanyaan apakah yang sebenarnya terjadi pada etnis Rohingya sehingga mereka meninggalkan Myanmar :

"Mereka bunuh orang Rohingya, tapi masalahnya mereka beberkan kepada seluruh dunia bahwa itu bohong. Mereka bilang Rohingya bakar sendiri rumah-rumah mereka. Ngeles mereka. Sekarang semua dunia udah tahu. Dulu media itu di sana nggak ada bebas. Kalo mereka liat hp kita, kamu video ya? Tsyungg.. langsung habis dia. Binatang aja mereka bunuh. Sapi nggak ada apa-apa, ambil piso, pisahkan kulit.” (Abu Zubair, 24 Januari 2018).

Etnis Rohingya juga kerap mendapatkan perlakuan diskriminasi dari pemerintahan Myanmar, misalnya dalam memperoleh pendidikan. Negara memperlakukan etnis Rohingya dengan cara yang tidak adil. Salah satu bentuk ketidakadilan dalam aspek pendidikan tersebut adalah penekanan terhadap nilai evaluasi atau nilai akhir kelulusan bagi etnis muslim Rohingya. Bentuk ketidakadilan tersebut menyebabkan mereka terancam tidak lulus, sedangkan yang bukan termasuk etnis muslim Rohingya, kelulusannya akan dipermudah meskipun nilai pendidikannya tidak mencapai target. Tentara Myanmar juga kerap menghalangi etnis Rohingya ketika hendak pergi ke sekolah dan kemudian memaksa mereka bekerja tanpa upah. Istilah kerja paksa seperti yang dialami oleh etnis Rohingya tersebut juga pernah terjadi di Indonesia yang dikenal dengan kerja rodi dan terjadi pada zaman kolonial Belanda. Berikut adalah kutipan hasil wawancara dengan informan :

"Misalnyakan, saya dulu kecil pergi ke sekolah. Kita dulukan, di kampung- kampung banyak jalan kaki pergi ke sekolah. Tiba-tiba jumpa mereka, tentara Myanmar. Hei, Mau kemana? Saya mau sekolah. Sekolah? Eehehehe.. ketawa dia, mau jadi apa kau he? langsung di kau-kau kan. Sekolah lah. Nggak ada. Langsunglah bawa pos suruh kerja saya. Makan saya mana? Minum saya mana? Saya juga nggak tau. Langsung disuruh pulang. Besok jumpa lagi panggil lagi. Besoknya jumpa lagi, panggil lagi. Begitu terus.. terus.. Di sana juga kita susah kerja. Kalau ada kerja mereka kasih kita batu- batu besar, kita kerja keras. Kalo misalnya kita capek, nggak bisa. Mereka pukul. Macam kerja paksa la. Batu itu mereka jual, mereka juga yang berhasil.” (Mhd Yunus, 3 Januari 2018). 
Hal ini juga sesuai dengan temuan penelitian yang pernah dilakukan oleh Anna dengan judul "Studi Eksistensi Etnis Rohingya di bawah Tekanan Pemerintah". Dalam penelitian tersebut dinyatakan bahwa etnis yang terletak di Myanmar Utara ini terpinggirkan oleh pemerintahan junta militer dan di wilayah Rohingya, para pengajarnya biasanya berasal dari golongan etnis Budha Rakhine, yang seringkali menghalangi kesempatan untuk mendapatkan pendidikan bagi masyarakat Rohingya. Pemerkosaan dan kerja paksa adalah hal yang cukup lazim bagi etnis Rohingya di Myanmar. Tentara Myanmar kerapkali meminta uang dari mereka dan ketika mereka tidak dapat membayar, mereka akan ditahan dan disiksa (Anna, 2013: 12).

Negara Myanmar juga tidak mau jika etnis muslim Rohingya ini menjadi salah satu etnis yang maju dan berkembang. Berdasarkan pengakuan salah satu informan, etnis Rohingya di Myanmar adalah etnis yang dikenal sebagai pekerja keras dan mandiri. Biasanya mata pencaharian mereka bergantung pada hasil tani, dagang, dan sebagai nelayan. Setiap kali etnis Rohingya mempunyai kehidupan yang baik, tentara-tentara Myanmar akan datang merampas semua harta milik mereka.

Tentara Myanmar kerap kali datang untuk merampas hasil tani, dagang dan hasil nelayan yang telah mereka usahakan. Setelah harta mereka dirampas, etnis Rohingya akan bangkit dan mencoba untuk memulai hidup baru dengan mulai bekerja untuk mendapatkan penghasilan kembali. Namun, tentara Myanmar datang kembali dengan membawa senjata untuk merampas harta dan segala sesuatu yang berharga milik etnis Rohingya. Siapapun yang melakukan perlawanan, maka mereka akan ditembak mati. Hal ini menyebabkan etnis Rohingya tidak pernah mempunyai kehidupan yang layak sampai saat ini. Berikut ini adalah kutipan hasil wawancara dengan informan:

"Di sana orang Rohingya kaya. Sekarang pemerintah Myanmar itu semua harta ditarik. Semua diambil. Isi dalam dompet sedikit juga nggak ada. Barupolisi datang banyak, siap megang senjata. Masalahnyakan kita lagi duduk- duduk gini, mereka datang. Kita lari karna takut. Langsung mereka tembak. Kalo kita tidak lari juga, datangi mereka. Mau pukul dulu, siksa dulu. Suka hati mereka." (Mhd. Khaliq, 10 Maret 2018).

Tentara Myanmar tidak hanya merampas harta benda milik etnis Rohingya saja. Pola tindakan kekejaman yang dilakukan oleh tentara Myanmar tersebut semakin meluas pada kaum perempuan. Tentara Myanmar pun melakukan kekerasan seksual terhadap perempuan-perempuan etnis Rohingya. Adapun kutipan hasil wawancara dengan informan adalah

"Mereka langsung masuk rumah. Langsung perkosa wanita-wanita. Setelah mereka perkosa langsung motong atau tembak. Mereka ambil yang berharga semua. Bakar juga, siksa juga, suka hati mereka. Terus kita Rohingya ini tidak boleh maju, karena udah maju sikit nol lagi, maju lagi sikit, nol lagi. Gitu-gitu teruslah." (Nurul Amin, 24 Januari 2018).

Pada tahun 2010, berdasarkan data yang diperoleh dari hasil wawancara dengan informan, etnis Rohingya juga sudah tidak memiliki hak pilih di negara asalnya. Negara merampas semua dokumen-dokumen mereka dengan cara yang halus, dimana sebelum pemilihan umum negara mengatakan bahwa mereka memerlukan dokumen-dokumen seperti Kartu Keluarga (KK), Kartu Tanda Penduduk (KTP), dokumen tanah, serta dokumen rumah untuk keperluaan negara. Namun setelah negara memperoleh dokumen-dokumen tersebut, negara mengklaim etnis ini sebagai etnis ilegal di Myanmar. Tentara dan media Myanmar juga kerap menyebarkan berita bohong/palsu kepada dunia tentang insiden tersebut. Berikut ini adalah kutipan hasil wawancara dengan informan: 
Vol 2 No. 2, 2019, 70-86

DOI: https://doi.org/10.30596/persepsi.v2i2.3951

"Mereka pandai cantik main, mereka tarik semua dokumen, dokumen tanah kita, dokumen rumah kita. Tahun 2010 ada undi (milih), langsung dia stop. Orang Rohingya tidak boleh ikut undi lagi. Mereka masuk rumah. Ayo..ayo..ayo.. sini dokumen, kami butuh. Misalnya KK, KTP, langsung mereka bawa. Nggak dikembalikan lagi. Dan sebelum tahun 2010, semua kami di sana bisa. Kami bisa jadi apa aja lawyer, mentri, dokter, jadi polisi. Tapi kenapa setelah 2010 itu kami nggak ada bisa semua? Karna kami warga negara sanakan? Sekarang mereka tarik semua. Suka hati merekalah semua. Mereka bohong, macam mana cara supaya kita bisa hilang." (Roshid, 24 Januari 2018).

Berdasarkan perlakuan tersebut, etnis Rohingya terpaksa melakukan perpindahan dari negara asalnya akibat situasi dan kondisi yang tidak memungkinkan untuk bertahan hidup. Proses kedatangan yang ditempuh oleh masing-masing informan berbeda-beda. Mereka berlayar menggunakan kapal dari Myanmar menuju negara-negara lain, seperti Malaysia dan Thailand, bahkan sampai ke Kota Aceh. Setelah melewati proses perjalanan yang sangat panjang, akhirnya mereka ditempatkan di Camp pengungsian Hotel Pelangi Kota Medan.

Bapak Mhd Yunus sebagai informan pertama adalah etnis Rohingya yang tiba di Malaysia pada tahun 2011. Setelah beberapa lama berada di Malaysia, beliau berniat untuk pergi ke Australia, namun pihak Imigrasi menahan beliau karena tidak memiliki dokumen. Pihak imigrasi kemudian menempatkan beliau ke Rudenim Pangkal Pinang, kemudian beliau dipindahkan ke Hotel Pelangi Kota Medan. Berikut ini adalah kutipan hasil wawancara dengan informan:

"Saya awalnya tahun 2011 dari Myanmar tiba di Malaysia melalui kapal. Di sana kerja. Terus niatan saya mau pergi ke Australia, tapi saya ditangkap polisi karena nggak ada bawa dokumen/identitas lengkap. Kemudian di Indonesia saya pertama-tama masuk di Pangkal Pinang, lalu dipindahkan ke Medan.” (Mhd Yunus, 3 Januari 2018).

Bapak Abu Zubair sebagai informan kedua berangkat menaiki kapal pada tahun 2011, dan tanpa disadari setelah tujuh hari berlayar beliau dengan rombongan etnis Rohingya lainnya sampai di laut lepas Thailand. Polisi Thailand tidak menerima mereka dan memutus mesin kapal yang mereka naiki. Kapal mereka pun terombang-ambing selama tujuh belas hari di laut lepas dan ditemukan oleh nelayan Aceh. Nelayan Aceh pun membantu mereka dengan mengaitkan tali ke kapal yang beliau tumpangi agar sampai ke tepi laut Aceh. Setelah sampai di Aceh beliau mendapatkan bantuan logistik dan tempat penampungan sementara selama dua puluh tiga hari.

Kemudian beliau diberikan harapan bahwasanya beliau akan mendapatkan negara ketiga jika beliau pindah ke Medan. Berikut ini adalah kutipan hasil wawancara dengan informan yang menceritakan proses kedatangannya hingga sampai di Hotel Pelangi Kota Medan:

"Dari Myanmar satu kapal 129 orang itu tanggal 16 Februari 2011, sampai 7 hari sampai di Thailand. Dari situ dari police Thailand dilepas di laut ambil gensetnya. Jadi kami nggak bisa jalan, nggak bisa kemana-mana. Di situ cuma dikasih mie aja udah. Dari situ kami sampai udah tujuh belas hari, sampai di daerah laut di Aceh. Dari abis itu, orang Aceh ketemu kami. Kami minta tolong dibantui. Datang kapalnya dikasih 1 kardus mienya 2 galon air minum. Dari situ kami ada yang genset rusak, itu dibenarin baru dihidupin satu hari udah jalan. Ada yang nampak banyak-banyak kapalnya minta tolong dia orang akhirnya diikat di belakang di apa karet ya? Langsung dia tanya di Aceh bisa naik nggak? Langsung dia diangkat apa dinaikin. Di Banda Aceh 1 bulan 17 hari. Orang Aceh itu baik kalilah. Saya dikasih harapan dapat negara ketiga makanya pindah ke Medan. 
Tapi nyatanya nggak ada. Habis itu pemerintah Indonesia dibantuin aaaa.. apa? Dari sana diberangkatkan ke Medan. Dikasih kartu pengungsi dibilangnya mau berangkat ke negara ketiga, dikasih harapan. Tapi ini udah 7 tahun belum sampe." (Abu Zubair, 24 Januari 2018).

Informan ketiga adalah Bapak Rosyid yang datang pada tahun 2012 dan sampai di Aceh kemudian dipindahkan ke Hotel Pelangi Kota Medan. Berikut ini adalah kutipan hasil wawancara dengan informan yang menceritakan kedatangannya hingga sampai di Medan:

"Myanmar ee... ke Aceh. Aa..Itu di tahun 2012. Aa... Naik kapal. Naik kapal itu aa.. sebanyak 55 orang. Setelah itu di tolong sama nelayan Aceh di sana. Dikasih makan, minum, baiklah mereka. Ramah juga." (Roshid, 24 Januari 2018).

Informan kelima adalah etnis Rohingya yang berasal dari Muangdow, Myanmar (Burma) bernama Abdul Khaliq. Informan berada di Hotel Pelangi pada tahun 2013. Berikut adalah kutipan hasil wawancara dengan informan:

“Awalnya saya sampai di Malaysia selama 5 bulan pada tahun 2012. Sebenarnya waktu itu saya pengen cari nafkah untuk anak-anak saya ada 3 orang. Setelah di Malaysia, saya rencana pergi ke Australia tanpa dokumen, tapi nasib saya buruk. Polisi tangkap di Bandar Lampung selama 6 bulan di sana. Abis itu saya dibawa imigrasi ke Pontianak, Kalimantan. Sampe akhirnya dipindahkan ke Hotel Pelangi Kota Medan pada tahun 2013." (Abdul Khaliq, 10 Maret 2018).

Berdasarkan hasil wawancara dengan kelima informan etnis Rohingya tersebut, penulis dapat menyimpulkan bahwa latar belakang kedatangan mereka ke berbagai negara disebabkan oleh tekanan dan perlakuan yang tidak manusiawi oleh pemerintah Myanmar. Perlakuan tersebut diperoleh berdasarkan data di lapangan dimana pemerintah Myanmar melakukan perlakuan seperti diskriminasi, pembunuhan, pemerkosaan, penyiksaan, manipulasi data, dan pengusiran atau pemindahan penduduk secara paksa pada etnis Rohingya di Myanmar. Oleh karena itu, etnis Rohingya terpaksa meninggalkan negaranya untuk mencari masa depan atau kehidupan yang lebih baik di negara lain. Proses perpindahan tersebut akhirnya membawa mereka ke Pengungsian Hotel Pelangi Kota Medan.

Proses perjalanan panjang yang telah di tempuh oleh etnis Rohingya ini, akhirnya membawa mereka ke Hotel Pelangi Kota Medan. Para pengungsi/pencari suaka yang berada di camp pengungsian Hotel Pelangi Kota Medan ini mendapatkan pengawasan dari Rudenim Medan. Rudenim adalah unit kerja di lingkungan kementerian yang menyelenggarakan urusan pemerintahan di bidang Hukum dan Hak Asasi Manusia yang melaksanakan urusan pendetensian orang asing. Sedangkan penanganan pengungsi dilakukan berdasarkan kerjasama antara pemerintah pusat dengan Perserikatan Bangsa-Bangsa melalui Komisariat Tinggi Urusan Pengungsi di Indonesia dan/atau organisasi internasional. Terkait lainnya karena telah memberikan fasilitas dan bantuan kepada mereka. Berikut ini adalah pernyataan informan pada saat diwawancarai tentang bagaimana perasaan mereka selama tinggal di Hotel Pelangi Kota Medan :

"Sebenarnya, aa.. sebenarnya kalo ikut kondisi Myanmar, di sini senang, gembira. Tapi namanya itu negara asalkan? Masalahnya kalo negara itu udah aman, lebih senang itukan, namanyakan asal kita lahir di sana kan.. tapi sekarang kondisi ini sekarang di Indonesia ini, kita alhamdulillah gembira, senang, pokoknya senangla kita di sini. Dan juga orang masyarakat sama kita juga ngak ada ganggu. Semua baik." (Mhd Yunus, 03 Januari 2018). 
"Baik. masyarakat di sini juga baik, ramah. Ngak ada ganggu. Polisi di sinijuga ngak ada tanya-tanya kalo kita keluar. Mana paspor? Orang mana? Biasa ajala. Kadang masyarakat sini kira kami orang Aceh. Dia tanya. Orang Aceh ya? Bukan.. jadi? Rohingya. Ooo.. mirip kayak orang Aceh. Tanya gitu-gitu ajala mereka." (Nurul Amin, 24 Januari 2018).

Kutipan hasil wawancara dengan Bapak Abu Zubair sebagai informan kedua ketika wawancara adalah sebagai berikut : "Senang. Terima kasih. Kami di kasih tempat tinggal, uang saku dari IOM. Tapi dikasih harapan terus dapat negara ketiga. Tapi udah 7 tahun ngak ada." (Abu Zubair, 24 Januari 2018).

Sementara data hasil wawancara dengan Bapak Roshid adalah : "Kalau perasaan kami di Indonesia ini, kami apa, yang bantu kami dari pemerintah Indonesia ini, sangat terima kasih. Dikasih tempat inap, biaya makan. Tapi satu, kami belum dapat negara ketiga." (Roshid, 24 Januari 2018).

Temuan tentang persepsi yang baik terhadap masyarakat Indonesia, khususnya masyarakat Kota Medan juga diungkapkan oleh informan kelima, yaitu: "Senang, di Indonesia, orang ramah, baik, hormat-menghormati agama punya orang lain. Tapi satu aja, kami ngak bisa lakukan apa-apa di sini." (Abdul Khaliq, 10 Maret 2018).

Selama berada di Hotel Pelangi Kota Medan, mereka tetap dalam peraturan dan pengawasan dari Rudenim Medan. Sesuai dengan PERPRES RI Nomor 125 Tahun 2016 tentang Penanganan Pengungsi Dari Luar Negeri yang mengatur tentang Pengawasan Keimigrasian pada Bab V Pasal 36 ayat 1-2, menyebutkan bahwa; (1) pengungsi wajib lapor diri setiap bulan kepada kepala Rumah Detensi Imigrasi sebagaimana dimaksud dalam Pasal 35 huruf c setempat untuk mendapat stempel pada kartu identitas khusus pada saat berada di tempat penampungan; (2) Pengungsi yang tidak melaporkan diri selama 3 (tiga) kali berturut-turut tanpa alasan yang dapat diterima, ditempatkan di Rumah Detensi Imigrasi.

Berdasarkan hasil wawancara dengan informan, tidak banyak aktivitas yang dapat dilakukan etnis Rohingya di Hotel Pelangi. Pada jam 20.00 WIB, mereka sudah harus berada di Hotel Pelangi. Aktivitas yang mereka lakukan di Hotel Pelangi kebanyakan digunakan untuk berbelanja, memasak, dan melakukan kegiatan olahraga sepak takraw di sore hari. Berikut ini adalah hasil wawancara kepada informan pada pertanyaan apakah aktivitas/progam yang dilakukan etnis Rohingya saat berada di Hotel Pelangi:

"Untuk anak-anak dari IOM ada kelas belajar bahasa Inggris, bahasa arab. Itu aja. Dewasa nggak ada. Ada jam malam juga. Jam 8 mesti di sini. Ada batasan. Sebulan sekali kita harus melapor ke imigrasi. Macam tahanan kota la kita-kita di sini. Tapi aturan itu ada baik juga la mungkin untuk keamanan kami di sini.” (Mhd Yunus, 3 Januari 2018).

"Sekarang di sini nggak ada aktivitas apa-apa. Kami nggak bisa kerja, menikah juga. Karna status negara. Kalau sore kami buat sendiri olahraga sepak takraw biar keluar keringat aja la. Kami pernah minta sama imigrasi supaya bisa kerja disini, tapi nggak bisa juga. Nggak tau hidup kami di sini, nggak jelas." (Abu Zubair, 24 Januari 2018).

"Olahraga takraw kalo sore-sore. Kami buat sendiri di belakang itukan.. Sama-sama biar sehat ajala. Lain cuma belanja ke pasar, shalat, masak, makan, tidur, bersihkan kamar, nonton. Gitu-gitu aja. Ada juga kita pergi Belawan harus melapor ke imigrasi sekali selama tiga puluh hari. Kalo tiga kali berturut-turut nggak melapor, dipulangkan lagi ke imigrasi." (Roshid, 24 januari 2014).

"Sekarang dari IOM, UNHCR apa pun di sini tidak ada. Program untuk anak- anak saja ada. seperti bahasa Inggris, lain apapun tidak ada lagi. Untuk kami dewasa tidak ada. Dulu ada Festival yang dibuat IOM. Kuliner makanan dari negara-negara pengungsi yang ada di sini. Ada juga pemeriksaan kesehatan sama kami." (Nurul Amin, 24 Januari 2018). 
"Di sini kan ada beberapa refugee. Saya lupa dari mana aja 5, 6 negara. Dari IOM pernah buat Festival tradisional makanan. Makanan Pakistan, Somalia, berbagai negara. Ada juga dancing anak-anak, Seminar program healthy. Education juga belajar bahasa Inggris. Tapi sekarang udah jarang. Untuk anak-anak aja ada." (Abdul Khaliq, 10 Maret 2018).

Berdasarkan lamanya etnis Rohingya berada di Hotel Pelangi Kota Medan, kontak komunikasi antarbudaya dengan masyarakat lokal merupakan suatu hal yang tidak dapat dihindari. Proses komunikasi antara etnis Rohingya dengan masyarakat lokal lebih sering berlangsung di pasar, ketika mereka hendak membelanjakan kebutuhan sehari-hari. Interaksi antara etnis Rohingya dengan masyarakat di sekitar pengungsian Hotel Pelangi Medan ini, terutama dengan pedagang di pasar membuktikan bahwa manusia adalah sebagai makhluk sosial yang membutuhkan interaksi dan komunikasi untuk dapat memenuhi kebutuhan hidup di lingkungan sosialnya.

Adapun kesiapan diri yang dilakukan informan ketika berinteraksi dengan masyarakat lokal di Kota Medan khususnya di pasar adalah dengan membangun kesadaran diri bahwa mereka adalah sebagai pengungsi/pencari suaka yang membutuhkan hidup di Medan. Maka secara otomatis sedikit banyaknya mereka akan bergantung atau membutuhkan masyarakat di sekitar lokasi pengungsian Hotel Pelangi, terutama kepada para penjual di pasar. Atas dasar adanya kebutuhan yang harus dipenuhi tersebut, etnis Rohingya telah melakukan adaptasi pada perilaku linguistik atau para linguistik seseorang (konvergensi) ketika berinteraksi. Dalam teori akomodasi komunikasi yang dikemukakan oleh Howard Giles mengatakan bahwa dalam berkomunikasi manusia dapat memiliki pilihan. Mereka mungkin menciptakan komunitas percakapan yang melibatkan penggunaan bahasa atau sistem nonverbal yang sama, atau mereka akan bekerja keras untuk beradaptasi.

Proses komunikasi etnis Rohingya dengan masyarakat lokal dimulai dengan mempelajari budaya setempat khususnya bahasa dan kode-kode berbicara yang dipakai oleh masyarakat lokal, agar terciptanya kesepemahaman yang sama. Namun perbedaan latar belakang kebudayaan yang berbeda bukanlah suatu hal yang mudah untuk dilalui. Hal tersebut merupakan suatu kendala pada saat melakukan interaksi.

Pada awal kedatangannya, etnis Rohingya sama sekali tidak dapat menggunakan bahasa Indonesia. Mereka hanya mampu menggunakan bahasa Inggris meskipun tidak fasih. Namun, berinteraksi dengan masyarakat lokal yang dapat menggunakan bahasa Inggris membuat mereka lebih mudah berkomunikasi dan mempelajari bahasa. Dan mereka akan merasa kesulitan untuk berkomunikasi atau mempelajari bahasa ketika berinteraksi dengan masyarakat awam yang tidak dapat menggunakan bahasa Inggris. Oleh sebab itu, mereka mulai mempelajari bahasa Indonesia dengan cara membuka diri kepada masyarakat lokal serta tidak segan untuk bertanya kepada siapa saja yang mereka jumpai tentang penggunaan bahasa Indonesia. Tidak adanya sarana atau program-program pembelajaran bahasa Indonesia yang disediakan di Hotel Pelangi Kota Medan, membuat mereka terdorong untuk mempelajari bahasa Indonesia secara otodidak (belajar sendiri).

Strategi yang digunakan oleh etnis Rohingya dalam mempelajari bahasa Indonesia adalah dengan cara sering berbaur dengan teman-teman yang bisa berbahasa Inggris dan bahasa Indonesia ketika di Malaysia atau negara yang pernah mereka datangi baik sebelum dan sesudah dipindahkan ke Hotel Pelangi Kota Medan. Berikut ini adalah kutipan hasil wawancara dengan informan: 
"Masalahnyakan sebelum ke Medan saya pernah di Malaysia. Di sana kan, kita kerja proyek, ketemu banyak sama orang Indonesia juga. Saya bilangkan.. friend.. friend... ini.. ini.. ini.. Ruti, ini.. ini.. ini.. susu, ini.. ini.. ini.. nasi. Pertama-tama saya sendiri yang usaha. Mereka kasih tau. Lalu saya tulis.” (Mhd Yunus, 3 Januari 2018).

"Misalnyakan saya mau beli sayur. Namanyakan saya nggak tau. Lepas nampak, di tunjuk ini.. ini.. gitu. Satu.. satu.. lepas itu, dikasih uangnya, berapa dia balek, dikasih ya gitu aja. Karnakan bahasanya nggak tau, jadi mau beli buah, pulsa, apa, ya tunjuk aja kasih uangnya. Kalau di jalan pun ketemu sama kawan langsung tanya. Ini apa? Ini apa? Gitu.. saya juga dulu pernah di Jakarta. Ada kawan saya kecil-kecil tapi, saya belajar dari sms. Belajar bahasa indonesia saya kira-kira 2 tahun 3 tahun." (Roshid, 24 Januari 2018).

Selain itu, informan juga membuat catatan-catatan kecil yang berisikan kosakata bahasa Indonesia. Catatan tersebut bertujuan untuk lebih memudahkan informan untuk mengingat dan mempelajari bahasa Indonesia, dengan cara membaca ulang kembali catatan tersebut pada sebuah kesempatan tertentu. Berikut ini merupakan pernyataan langsung dari informan pada saat wawancara :

"Belajar bahasa Indonesia pertamanya sulit, lama-lama bisa. Sudah bisa menyesuaikan diri. Di translate juga. Ditulis di buku juga. Belajar sendiri. Karna kami nggak ada belajar bahasa indonesia di sini, adanya bahasa Inggris sama bahasa arab, katanya dua bahasa itu penting, biar nggak susah kalo pergi mana-mana." (Nurul Amin, 24 Januari 2018).

Etnis Rohingya juga sering memanfaatkan google translate untuk mencari kata perkata dalam bahasa Indonesia yang belum mereka ketahui sebelumnya. Mereka juga tidak segan untuk langsung menanyakan bahasa yang tidak mereka pahami kepada teman sesama pengungsi maupun kepada security yang ada di Hotel Pelangi Kota Medan atau di tempat yang pernah mereka singgahi sebelumnya. Berikut ini adalah kutipan hasil wawancara dengan informan :

"Misalnyakan, ini sudah beli. Baru belikan baru tau namanya apa. Nantikan siap beli, tanya aja itu namanya apa. Nantikan itu juga ada di translate. Kami mau belanja, mau pergi jalanjalan, mau bicara sama kawan-kawan, kami butuh belajar, ditanya-tanyaan barang-barang apa nama, kalo ada kawan ditanya mau manggil gimana, kalo mau makan maggilnya kekmanakan. pertama-tama datang ke sini nggak pintar bahasa inggris. Cuma tau sedikitsedikit saja, ada orang Indonesia pintar bahasa Inggris jadi kami tanya. Gitu- gitu aja. Akhirnyakan udah 7 tahun, 1 tahun satu-satu bahasanya satu bulan selama 7 tahun udah berapa? Enam bulan saya udah bisa, karnakan ada kawan saya jual nasi, dekat sudah seperti saudara.. main ke rumahnya, dijaga. Dulu belum ada android, jadi kalo udah ada android saya tulis pake bahasa Inggris. Ada kawan, saya bilang Assalamu'alaikum.. How are you? Terus mereka bilang baik..trus saya bilang, ajari saya bahasa Indonesia. Akhirnya pake google translate dan kami tulis di buku. Dibaca, nengok-nengok, di baca." (Abu Zubair, 24 Januari 2018).

"Belajar bahasa aku pakai google translate, di sini juga ada dictionary ee.. kamus. Karna saya dari Myanmar belajar bahasa Inggris. Walaupun kurang pandai. Tapi Alhamdulillah saya bisa translate semua apa yang saya mau. Belajar bahasa Indonesia pertamanya sulit tapi aku senang aku belajar satu satu bahasa. Tapi pertamanya aku takut. Lama-lama biasa." (Abdul Khaliq, 10 Maret 2018).

Dari hasil penelitian yang dilakukan di lapangan, ternyata etnis Rohingya ini tidak hanya menggunakan komunikasi verbal dalam berinteraksi, tetapi mereka juga menggunakan bentuk komunikasi nonverbal. 
Salah satu informan etnis Rohingya yang pertama kali sampai di Malaysia menyaksikan temannya asal Myanmar yang menggunakan isyarat tangan ketika berinteraksi, yaitu dengan menekuk lengannya ketika ingin membeli nasi ayam hingga memberikan simbol/tanda lengan tersebut dibentuk seperti sayap seekor ayam yang sedang mengepak-ngepakkan sayapnya.

Proses komunikasi beberapa etnis Rohingya laki-laki dengan masyarakat lokal Kota Medan dapat dikatakan berlangsung dengan baik. Artinya mereka bersedia untuk membuka diri dan berinteraksi dengan masyarakat lokal di Kota Medan. Namun berbeda halnya dengan interaksi yang dilakukan oleh perempuan etnis Rohingya di Hotel Pelangi ini.

Proses komunikasi perempuan etnis Rohingya cenderung terbatas dan menutup diri dengan lingkungan di sekitarnya. Hal ini disebabkan oleh tradisi yang tetap mereka terapkan/pertahankan dari budaya asalnya sejak dari generasi- generasi sebelumnya, dimana perempuan cenderung berada di dalam rumah. Perempuan keluar rumah hanya pada keperluankeperluan tertentu seperti kepetingan untuk pergi ke rumah sakit. Biasanya perempuan etnis Rohingya akan memakai baju panjang (hijab) dan burka pada saat keluar rumah. Sementara yang melakukan aktivitas berbelanja kebutuhan sehari-hari dilakukan oleh laki-laki. Hal ini sesuai dengan pemaparan salah satu informan tentang tradisi perempuan di Myanmar:

"Masalahnyakan.. perempuan di negara kami, umur 14 tahun atau kalau sudah baliq la. Masuk rumah. Dia mau belajar, apa, ngak peduli. Langsung masuk rumah. Misalnya kalau dia mau belajar tentang agama, panggil guru ada adek, abang atau saudara, dia yang apa, ngajar. Kalau nggak mau belajar, udah stop, di rumah. Nanti satu tahun, dua tahun dijodohin sama orang tua. Nggak ada jodoh sendiri.” (Muhammad Yunus, 3 Januari 2018).

Berdasarkan hasil penelitian yang telah dilakukan, penulis juga menemukan bahwa antara perempuan dan laki-laki pada etnis Rohingya di Myanmar cenderung menjaga diri dalam pergaulannya dengan lawan jenis. Pada saat di Myanmar mereka tidak mengetahui adanya budaya berpacaran. Namun, setelah berada di Hotel Pelangi informan melihat budaya berpacaran tersebut sudah diadopsi oleh sebagian etnis Rohingya. Berikut ini adalah pernyataan dari informan:

"Terus masalah pacaran, pacaran kayaknya ada dari sini. Di sana nggak ada. Pacaran itu juga apa? Saya bingung, dengar. Ini banyak kali kalo saya masuk. Oo.. pacaran.. jadi udah biasala di hotel. Sebelumnya nggak ada pernah pikir, nggak ada pernah tau. Terus kalo perempuan di sana itu nggak ada kerja. Masalahnyakan kalo bisa, laki-lakilah kerja. Malu." (Muhammad Yunus, 3Januari 2018).

Berbeda dengan kebiasaan interaksi perempuan di Medan pada umumnya. Perempuan di Medan sudah terbiasa melakukan aktivitas di luar rumah seperti bekerja, sekolah, belanja kebutuhan sehari-hari di pasar, atau melakukan aktivitas- aktivitas lainnya.Dengan demikian, dapat disimpulkan bahwa perilaku komunikasi perempuan etnis Rohingya yang tertutup kepada masyarakat lokal dan mempertahankan tradisinya menandakan terjadinya strategi divergensi dalam teori akomodasi komunikasi. Divergensi dalam teori komunikasi dapat diartikan sebagai suatu usaha mencari perbedaan antara gaya komunikasi antar mereka yang saling berkomunikasi untuk meningkatkan jarak komunikatif dan meningkatkan keunikan mereka sendiri. Hal ini sesuai dengan pengamatan penulis di lapangan, bahwa tidak banyak perempuan etnis Rohingya yang melakukan interaksi dengan masyarakat setempat. Perempuan etnis Rohingya pada umumnya tidak dapat menggunakan bahasa Indonesia. Mereka juga tetap menggunakan bahasa asal mereka ketika mereka tidak mengerti bahasa Inggris maupun bahasa Indonesia. Kondisi kehidupan seharihari etnis Rohingya di camp pengungsian Hotel Pelangi Kota Medan sudah berbaur dengan masyarakat sekitar. 


\section{Kesimpulan}

Berdasarkan data hasil wawancara yang diperoleh dari 5 (lima) informan Komunikasi Antarbudaya Etnis Rohingya dalam Upaya Eksistensi Diri di Pengungsian Hotel Pelangi Kota Medan, maka dapat ditarik simpulan sebagai berikut:

1. Latar belakang kedatangan etnis Rohingya di Medan diakibatkan oleh konflik yang terjadi di negara asalnya, Myanmar. Konflik tersebut dapat dilihat melalui hasil wawancara dengan informan bahwa etnis Rohingya mendapatkan perlakuan berupa pembunuhan, pemerkosaan, pembakaran rumah, perampasan harta benda, penyiksaan dan kerja paksa, serta diskriminasi dalam memperoleh pendidikan pada etnis Rohingya di Myanmar. Perlakuan tersebut memicu etnis Rohingya untuk mencari perlindungan ke berbagai perbatasan termasuk Indonesia. Mereka juga mengharapkan kehidupan yang lebih baik setelah melakukan proses perpindahan tersebut.

2. Proses pencarian suaka oleh etnis Rohingya tersebut, akhirnya membawa mereka ke Hotel Pelangi Kota Medan. Keberadaan mereka selama berada di Hotel Pelangi mengakibatkan terjadinya proses sosial antara etnis Rohingya dengan masyarakat lokal di sekitar pengungsian Hotel Pelangi Kota Medan. Proses sosial yang terjadi pada etnis Rohingya sudah sampai pada tahap akomodasi. Akomodasi merupakan proses penyesuaian sosial yang terjadi dalam sebuah interaksi. Adapun bentuk-bentuk penyesuaian (adaptasi) yang dilakukan oleh etnis Rohingya di pengungsian Hotel Pelangi Kota Medan adalah dalam bentuk bahasa, makanan, pakaian, cara beribadah, dan kondisi geografis.

3. Strategi konvergensi yang dilakukan etnis Rohingya dalam aspek bahasa adalah dengan mempelajari bahasa Indonesia secara otodidak dalam bentuk komunikasi verbal maupun non verbal. Sedangkan divergensi adalah suatu keadaan dimana individu dapat memilih untuk mencari perbedaan antara gaya komunikasi mereka sehingga dapat meningkatkan jarak komunikatif dan meningkatkan keunikan mereka. Strategi divergensi yang dilakukan etnis Rohingya dapat dilihat dari upaya mereka bertahan pada masakan cita rasa pedas dan memasak makanan dengan cita rasa yang khas asal Myanmar dengan menggunakan banyak bumbu atau rempah-rempah. Strategi divergensi lainnya yang ditemukan penulis pada etnis Rohingya berupa kurangnya usaha perempuan etnis Rohingya untuk beradaptasi dengan lingkungan sekitarnya. Hal ini disebabkan oleh tradisi yang sudah melekat pada etnis Rohingya dari generasi ke generasi. Mereka terbiasa di dalam rumah sejak usia baliq/dewasa dan hanya keluar pada kebutuhan tertentu.

4. Etnis Rohingya di Hotel Pelangi Kota Medan ini berada di bawah pengawasan Rudenim Medan. Selama berada di sana, etnis Rohingya harus taat pada aturan keimigrasian karena status mereka juga masih sebagai pengungsi yang tidak memiliki kewarganegaraan. Mereka tidak dapat hidup normal seperti orang-orang pada umumnya.

Mereka tidak dapat mencari pekerjaan dan tidak dapat menikah dengan masyarakat lokal. Keadaan tersebut menyebabkan mereka terdorong untuk menikah dengan masyarakat lokal, meskipun pernikahan tersebut ilegal. Berdasarkan analisis penulis di lapangan, pernikahan yang berlangsung antara etnis Rohingya dengan masyarakat lokal Kota Medan merupakan suatu upaya eksistensi diri agar dapat memperoleh kewarganegaraan di Indonesia.

\section{Daftar Pustaka}

Abidin, Zainal.(2014). Filsafat Manusia Memahami Manusia Melalui Filsafat, PT. Remaja Rosdakarya, Bandung.

Afrizal. (2015). Metode Penelitian Kualitatif Sebuah Upaya Mendukung Penggunaan Penulisan 
Kualitatif Dalam Berbagai Disiplin Ilmu, Jakarta: Rajawali Pers, Jakarta.

Gunawan, Imam. (2013). Metode Penelitian Kualitatif Teori \& Praktik, Jakarta: Bumi Aksara.

Idrus, Muhammad. (2009), Metode Penelitian Ilmu Sosial, Jakarta: Erlangga. Kementerian Agama RI, (2010). Al-Qur'an Terjemah dan Penjelasan Ayat tentang Wanita Shafiya, Solo: PT. Tiga Serangkai Pustaka Mandiri.

Kriyantono, Rachmat. (2006), Riset Komunikasi (Disertai Contoh Praktis Riset Media, Public Relations, Advertising, Komunikasi Organisasi, Komunikasi Pemasaran), Jakarta: Kencana Prenada Media Grup.

Moleong, Lexy. (2006). Metodologi Penelitian Kualitatif, Bandung: PT. Remaja Rosdakarya.

Mulyana, Deddy, dkk. (2006). Komunikasi Antarbudaya (Panduan berkomunikasi dengan orangorang Berbeda Budaya), Bandung: PT. Remaja Rosdakarya.

Nawawi, Hadari. (2003). Metode Penelitian Bidang Sosial, Yogyakarta: Gadjah Mada University Press.

Ridwan, Aang. (2016). Komunikasi Antarbudaya Mengubah Persepsi dan Sikap dalam Meningkatkan Kreatifitas Manusia, Bandung: CV. Pustaka Setia.

Roeckelein, John E. (2013). Kamus Psikologi (Teori, Hukum dan Konsep). Jakarta: Kencana Prenadamedia Group.

Ruben, Brent D. \& Stewart, Lea P. (2013). Komunikasi dan Perilaku Manusia. Jakarta: Rajawali Pers.

Setiadi, Elly M. Usman Kolip, (2011). Pengantar sosiologi Pemahaman Fakta Dan Gejala Permasalahan Sosial: Teori, Aplikasi, Jakarta: Dan Pemecahannya. Kencana Prenadamedia Group

Soekanto, Soerjono. (2012). Sosiologi Suatu Pengantar, Jakarta: Rajawali Pers

Susetyo, Heru, dkk. (2013), Rohingya : Suara Etnis Yang Tak Boleh Bersuara, Jakarta: PAHAM Indonesia.

Suyanto, Bagong. (2005). Metode Penelitian Sosial Berbagai Alternatif Pendekatan, Jakarta: Prenadamedia Group.

Pelly, Usman. (1998), Urbanisasi dan Adaptasi, Jakarta: PT. Pustaka LP3ES.

Sumber Lain :

Adelia, Citra. "Perubahan Kebijakan Pemerintah Bangladesh Terhadap Kaum Rohingya Di Perbatasan Bangladesh-Myanmar." Universitas Airlangga. 2.1 (2003) di akses 10 September 2017<http:// unair.ac.id>

Aulia, Rina. Roswita Santia Dewi, Rahmi Fauzia. "Analisis Fenomenologi Eksistensi Narapidana Pelaku Pembunuhan Berencana Di Lembaga Pemasyarakatan.” 2.1 (April 2015): 14. Diakses 4 Maret 2018.< ppjp.unlam.ac.id>

Hartati, Anna Yulia. "Studi Eksistensi Etnis Rohingya Di Bawah Tekanan Pemerintah Myanmar." 2.1 (April 2013): 12. Diakses 4 Maret 2018<https://www.publikasiilmiah.unwahas.ac.id >

Vysca, Derma Oriza1. Reni Nuraeni, Ayub Ilfandy Imran. "Proses Adaptasi Dalam Menghadapi Komunikasi Antar Budaya Mahasiswa Rantau Di Universitas Telkom." Fakultas Ilmu Komunikasi Universitas Telkom. 3. 2 (Agustus 2016): 2382 diakses 9 September

2017https://openlibrary.telkomuniversity.ac.id

Pratiwi, Raiza Noor. 2016, "Studi Fenomenoologi : Eksistensi Diri Pada Penyandang Tuna Daksa Dewasa Awal Akibat Kecelakaan", Surakarta.

Undang Undang Republik Indonesia No. 40 Tahun 2008 Tentang Penghapusan Diskriminasi Ras dan Etnis. Diakses pada 11 September 2017. www.hukumonline.com 
Vol 2 No. 2, 2019, 70-86

DOI: https://doi.org/10.30596/persepsi.v2i2.3951

Yohana, Nova. Ringgo Eldapi Yozani. "Akomodasi Komunikasi Antarbudaya Imigran Ilegal Asal Afganistan Dengan Masyarakat Kota Pekanbaru." 11.02 (September 2017): 98 diakses pada 17 September $2017<$ journal.trunojoyo.ac.id> 